2013-06-06

\title{
Ethical Metafiction in Dickens's Christmas Hauntings
}

Mark Brian Sabey

Brigham Young University - Provo

Follow this and additional works at: https://scholarsarchive.byu.edu/etd

Part of the English Language and Literature Commons

\section{BYU ScholarsArchive Citation}

Sabey, Mark Brian, "Ethical Metafiction in Dickens's Christmas Hauntings" (2013). Theses and Dissertations. 4045.

https://scholarsarchive.byu.edu/etd/4045

This Thesis is brought to you for free and open access by BYU ScholarsArchive. It has been accepted for inclusion in Theses and Dissertations by an authorized administrator of BYU ScholarsArchive. For more information, please contact scholarsarchive@byu.edu, ellen_amatangelo@byu.edu. 


\section{Ethical Metafiction in Dickens's Christmas Hauntings}

\section{Brian Sabey}

A thesis submitted to the faculty of

Brigham Young University

in partial fulfillment of the requirements for the degree of

Master of Arts

Steven C. Walker, Chair

Jamie Horrocks

Paul A. Westover

Department of English

Brigham Young University

June 2013

Copyright (C) 2013 M. Brian Sabey

All Rights Reserved 


\author{
ABSTRACT \\ Ethical Metafiction in Dickens's Christmas Hauntings \\ M. Brian Sabey \\ Department of English, BYU \\ Master of Arts
}

Many critics have examined metanarrative aspects of Dickens's writing, and many have studied Dickens's ethics. None, however, has yet assessed the ways in which Dickens's directly interrogates the ethics of fiction. Surprisingly philosophical treatments of the ethics of fiction take place in A Christmas Carol and A House to Let, both of which turn the ghost story of the traditional winter's tale to metafictional purposes. No one has yet dealt with Dickens's own meta-commentary on the ethics of fiction with the degree of philosophical nuance it deserves.

Writings about the ethics of Dickens's fiction (and of fiction generally) often involves a simplistic separation of the real and the fictional: the text is ethical inasmuch as it effects positive change in the "real world." Yet Dickens constantly blurs the line between the real and the fictional. He adopts a somewhat Kantian stance, namely that both the real and the fictional are fundamentally imagined. Dickens reflexively makes the ghosts in A Christmas Carol embodiments of the fictional imagination, seen most explicitly in the Ghost of Christmas Past, who is closely associated with the narrator, with imagination, with memory, and with fiction. The other two spirits also personify aspects of the fictional imagination: that of Christmas Present embodies social imaginings; the Ghost of Christmas Yet to Come embodies intentions. Dickens shows that these imagined realities are crucial parts of the real, proving that fiction cannot be defined as that which is merely "imagined." How, then, is "fiction" to be defined? Dickens's answer anticipates Levinas: the ethical encounter determines the real as real; its absence is what defines fiction.

A House to Let is also strongly Levinasian: its very structure makes it a parable of the ethical relation. The plot centers on Sophonisba's "haunting" by an eye seen in the supposedly uninhabited house to let opposite. This "eye" and its effect are described in terms that equate it with the Levinasian "face," or the foundational ethical reality that precedes and conditions all discourse. Sophonisba reacts to this haunting by enlisting her closest male companions, Jarber and Trottle, to investigate the house. These two characters come to symbolize different general comportments by their reactions. The text unfavorably represents Jarber's primarily narrative orientation, and approves Trottle's response, which disrupts narrative self-satisfaction in favor of real-world intervention in behalf of the Other. There is a productive friction, then, between the metafictional message of $A$ Christmas Carol (looking back to Kant and emphasizing fiction's positive effects) and that of $A$ House to Let (looking forward to Levinas and emphasizing fiction's ethical dangers), evidencing Dickens's complex awareness of both narrative and prenarrative levels of ethical reality.

Keywords: Dickens, Levinas, Kant, A House to Let, A Christmas Carol, ethics of fiction 


\section{ACKNOWLEDGMENTS}

It is a truth universally acknowledged that a busy professor with a full load of classes is not likely to want another thesis committee position — and yet Steve Walker, Jamie Horrocks, and Paul Westover graciously accepted my request in the first place and then proceeded to help me through each step from prospectus drafts to final draft. Without exception, they have been far more generous with their time than I had any right to expect. Their standards have been rigorous and exacting (Jamie Horrocks deserves special mention in this regard), and my thesis is much stronger because of it. 
Table of Contents

Ethical Metafiction in Dickens's Christmas Hauntings......................................................... i

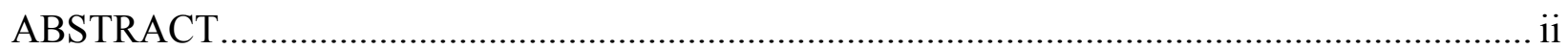

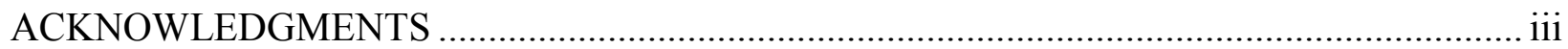

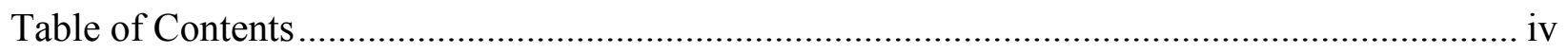

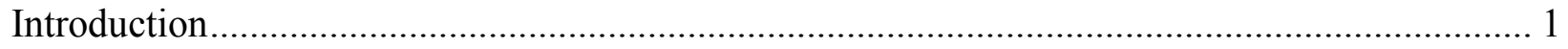

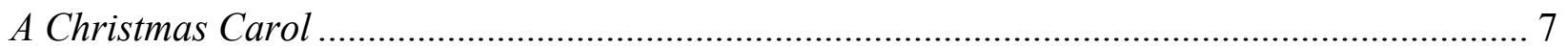

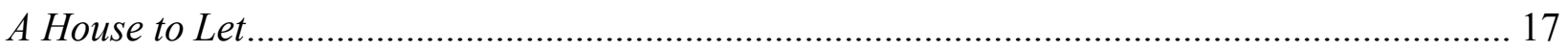

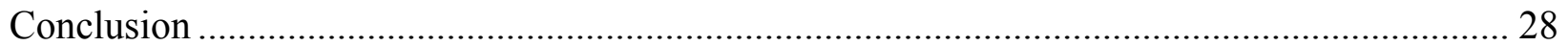

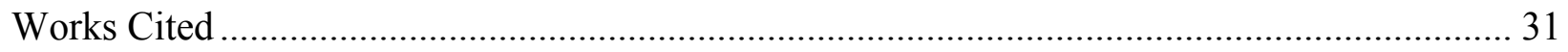




\section{Introduction}

Dickens was deeply interested in the ethics of fiction. As a social commentator, he tried to use fiction to persuade his readers to work for ethical progress in society, but he was also concerned with the personal ethical benefits and dangers of reading. These interests regularly animated his fiction, creating an ethical meta-commentary that runs through the whole Dickensian corpus. Though I here examine only two Christmas texts, nearly every novel can profitably be read for its metafictional content. Among those that are especially concerned with the ethics of reading are Hard Times, David Copperfield, and Oliver Twist. Hard Times is fundamentally an apology for "fancy" (a term closely associated with fiction at the time); Dickens shows how fancy is morally and socially necessary. Martha Nussbaum's reading of Hard Times convincingly shows that Dickens is both arguing for and exemplifying the power of novels to put human realities into perspective more accurately than political economy can. Their ethical efficacy outstrips that of political economy, which tends to reduce individuals to rational, self-interested, choice-making units, whereas novels do not lose track of the particularity and personality of individuals ("Literary Imagination" 878). Nussbaum also considers the metafictional element of David Copperfield, wherein the somewhat quixotic author-protagonist describes the role novels played in his life during the tyranny of the Murdstones: they served as his only friends, keeping his imagination and spirit alive (Love's Knowledge 230). Oliver Twist shows an awareness of the darker potentialities of reading, asserting, as Patrick Brantlinger points out, that bad reading (such as The Newgate Calendar) can corrupt youth (71). Brantlinger uses Oliver Twist as one example of nineteenth-century novelistic self-questioning, proving that Dickens was not alone in this metafictional impulse: many other novels responded self-critically to Victorian culture's well-documented ambivalence towards the moral value of fiction. 
Surprisingly, some of Dickens's most profound work of the ethics of fiction may take place in two short works that seem philosophically unassuming, namely A Christmas Carol (1842) and A House to Let. The latter is Dickens's 1858 Christmas number in Household Words, a basically forgotten sibling-text to $A$ Christmas Carol. Taken together, the two texts form a remarkably balanced and nuanced treatment of the subject. They both invoke the Christmas trope of hauntings (a remnant of the ancient winter's tale tradition) but use their respective hauntings as symbols of the ethical impulse in order (among other things) to address the ethics of fiction. $A$ Christmas Carol emphasizes the power of fictive texts to bring about ethical progress: despite the decades-long hardening of Scrooge's heart, the novels he read as a forlorn child on Christmas help melt his icy interior. Balancing the positive account of A Christmas Carol, A House to Let unfavorably contrasts the passive consumption of narrative with the doing of good deeds. The ethical metafiction of these Christmas hauntings reflects the Kantian philosophy of imagination that preceded Dickens and anticipates the postmodern ethical thought of Emmanuel Levinas.

Most commentaries on the ethics of Dickens's fiction, such as Barbara Hardy's The Moral Art of Dickens, examine the relationship between Dickens's novels and his society. Jon B. Reed reads Great Expectations as an ethical defense of the genre, positing "the virtues of [novelistic] narrative as a spur to social progress" (656, emphasis added). Mary-Catherine Harrison employs recent psychological research to explain how Dickens's fictional characters fostered real-world empathy, recounting how A Christmas Carol effectively called forth a "surge in charitable giving" in the spring after its release (271). The assumption underlying such work is that the ethical significance of art lies in its capacity to improve the "real world." Such scholarship is instructive but tends to take the opposition of the real and the fictional as an assumed premise, while Dickens constantly blurred these categories. The undefended assumption 
of the opposition of the real and fictional does not invalidate such scholarship: as Dickens would also grant, there is a difference between the two, and that difference need not be exhaustively delineated before scholarship can treat the effects of the one on the other. Still, the delineation of the real and the fictional remains an important pursuit, and one which might further illuminate or helpfully qualify such scholarship.

Many general theorists of the ethics of fiction have similarly located fiction within a "real world" context and then proceeded to demonstrate that fiction can effect change within that context. Of these, Martha Nussbaum is especially relevant, because she both examines the relationship between ethical philosophy and literature and regularly cites Dickens. In Love's Knowledge, Nussbaum argues that the novel is in some ways a more adequate form for pursuing ethical questions even than the traditional forms used by ethical philosophers. She asserts that novels and ethical philosophy are to some degree pursuing the same concern—namely, how best to live (see Nussbaum's “Introduction: Form and Content, Philosophy and Literature”).

Though Nussbaum does differentiate between the real and the fictional, she cannot be accused of failing to address the difference between the two. She clearly recognizes that the line between the imagined and the real is a blurry one. Further, she recognizes that Dickens forcefully illustrates this blurriness: she points out the implicit claim in Hard Times that "We never know for sure the contents of [another person's] heart; we have a choice, only, between a generous construction and a mean-spirited construction" ("Literary Imagination" 898). For Nussbaum, as for Dickens, to have any idea of another person we must imagine that person, and how we do so is ethically significant. As I hope to show, Dickens would also agree that the same principle applies to broader realities: things do not mean on their own; rather, they require imaginative construction to become meaningful. However, Nussbaum is mainly concerned with the practical 
ability of novels like Hard Times to encourage generous rather than mean-spirited constructions and not with the theoretical significance of Dickens's own demarcation of the real and the fictional. Nussbaum leaves open the line of inquiry that this paper pursues: if reality is fundamentally imagined, what then, according to Dickens, separates the real from the fictional, and how is an ethics of fiction to be conceived? No one has yet dealt with Dickens's own metafictional exploration of these questions with the degree of philosophical nuance it deserves. Dickens embraces neither a simplistic categorical segregation of the real and the imagined nor a total blending of the real and the fictive. Against the first position, A Christmas Carol adopts a somewhat Kantian stance — namely, that the imagination doesn't divide the real from the fictional, since the imagination is always involved in all meaningful experience, including, especially, sympathy with others. Against the second position, A Christmas Carol also aligns itself (avant la lettre) with Levinasian thought, as A House to Let does more strongly, by suggesting that a passive ethical responsiveness precedes and conditions all subsequent meaning, including imagined or narrative meaning. This combination of philosophical ideas instills a certain friction in Dickens's Christmas texts: which is the most fundamental ethical reality, the active imagination of others or a passive responsiveness to the presence of the Other? To do Dickens justice we must understand both the Neo-Kantian and the Proto-Levinasian elements of his metafiction. From this enriched perspective it will still be true that Dickens posits fiction's responsibility to improve the real world, but with this difference: the realness of the real world will be understood to be established by the relation to the Other rather than by its independence from imaginative construction.

Let me qualify my claims at the outset. I hope to say something about what Dickens's texts suggest about the ethics of fiction, but I am not necessarily claiming anything about 
Dickens's self-conscious philosophical commitments. Not without reason, Dickens has rarely been read for the philosophical content of his texts. Part of his project, after all, was to shift emphasis away from abstract reason and theory (what most people, including many philosophers, consider the proper domain of philosophy) and toward imagination and sociality. His disdain for Utilitarian thought and his well-documented aversion to elaborate theological systems are cases in point: as Nussbaum shows, he rejects such abstractions in favor of imaginative engagement with the "world of particulars" (Love's Knowledge 230). Yet imagination and sociality, too, are philosophically significant topics, and Dickens treats both with sufficient sensitivity and intelligence to justify the resonance I see in his texts with Kantian and Levinasian formulations of the same respective subjects. This resonance constitutes a surprising and underappreciated philosophical engagement with the ethics of fiction—one that reflects Kantian and pre-figures Levinasian concepts in such a way as to place Dickens in dialogue with the history of modern philosophy. Yet this does not make Dickens a philosopher. Perhaps, instead, the texts' philosophical richness suggests that careful representation will tend to express more than intended - as, for example, a skilled Victorian landscape painter all but ignorant of geology could nonetheless express truths about the landscape that would be fully explicated by science only decades later.

Bradly Fruhauff's dissertation, "Dickens and the Ethics of Genre: Reading the Gothic and Sentimental After Levinas," is of all Dickens scholarship perhaps the most closely related to my own. Fruhauff's excellent work provides a sort of "second witness" for my project: Fruhauff treats similar Dickens texts with a similar methodology and comes to related conclusions. He sees in various texts, including A Christmas Carol and The Haunted Man, moments when what Levinas scholar John Caruana calls the "ethical intrigue" interrupts the "drama of being"-when 
Dickens's narrative constructions pulsate with the fundamental ethical realities that precede narrative construction (Caruana 251; Fruhauff 10). He uses Levinas to explicate the ethical message of Dickens's texts, contextualizing his use of Levinas by referring to theories of sympathy and the sublime contemporaneous with Dickens (though he does not reference Kant). Fruhauff views gothic and sentimental tropes (such as Dickens's hauntings) as affective responses of the post-Enlightenment self to Otherness, and he uses Levinasian insight to deepen our reading of such responses. He finds little precedent among literary critics for this mode of scholarship:

While some scholars have been working with Levinas in a theoretical capacity, or as a hermeneutic for contemporary texts, little to no work has been done that tries to place Levinas within a broader literary-philosophical history. ... Furthermore, no one to my knowledge has attempted to draw connections between Levinas's insights into Enlightenment philosophy and the genres that emerged contemporaneously with it. Not surprisingly, then, few people have treated Dickens's use of Gothic and sentimental genre conventions as anything other than politically or culturally significant. (12)

My project differs in that it is Dickens, not Levinas, who will be placed in the broader literary-philosophical history; but still, it is Dickens, Levinas, and Enlightenment philosophy that are explored by placing them in dialogue with each other-simultaneously inserting Dickens's literary texts into philosophical history and mapping that history within the literary field of Dickens's texts. In both projects the question at issue concerns the ethics of fiction. Fruhauff concludes, and I concur, that fiction such as Dickens's novels can be ethically useful in bringing about a world "more hospitable to the goodness we all desire" (280). 


\section{A Christmas Carol}

For current purposes, my literary-philosophical map of Dickens's ethical metafiction begins with A Christmas Carol, the first of all his Christmas hauntings. One of its central contentions is that human sympathy involves human imagination. By itself, this is not particularly original—Adam Smith's 1759 book The Theory of Moral Sentiments posits that sympathy is fundamentally an act of imaginative identification with another person. In other words, according to Smith, real-world sympathy means imagining real-world people:

How selfish soever man may be supposed, there are evidently some principles in his nature, which interest him in the fortune of others, and render their happiness necessary to him.... [Our senses] never did and never can carry us beyond our own persons, and it is by the imagination only that we can ... place ourselves in [our brother's] situation ... and thence form some idea of his sensations. (3)

Dickens follows Smith, then, in asserting that the imagination enables sympathy. What makes $A$ Christmas Carol metafictional and ethically interesting is that Dickens blurs the boundaries between reality and fiction, suggesting, for example, that imagining fictional characters enables real-world sympathy. Of course, Dickens intended his short novel to enable his readers' sympathy with the poor and suffering — an obvious level at which the fictional imagination enables real-world sympathy. More interestingly, within Scrooge's "real world," it is the fictional imagination that rekindles his social sympathies. The hauntings that reawaken Scrooge's ethical being are explicit symbols of fictive texts, and they act on Scrooge just as the novel is to act on readers: the fictive hauntings enable sympathetic engagement with others.

Dickens conspicuously announces the metafictional nature of the hauntings with the entrance of the Ghost of Christmas Past: 
The curtains of his bed were drawn aside, I tell you, by a hand. Not the curtains at his feet, nor the curtains at his back, but those to which his face was addressed. The curtains of his bed were drawn aside; and Scrooge, starting up into a halfrecumbent attitude, found himself face to face with the unearthly visitor who drew them: as close to it as I am now to you, and I am standing in the spirit at your elbow. (24)

The jarring phrase "I tell you" introduces the narrative intrusion; "I am standing in the spirit at your elbow" then claims for the narrator a relationship with the reader analogous to the spirit's relation with Scrooge. The effect is complexly compelling: it places the ghost on the same ontological level as the narrator and, perhaps by extension, as Dickens; the narrator, as analogue of the ghost, is endowed with the same mission of reclamation, while the reader, as analogue of Scrooge, is implied to be in need of that reclamation. Finally, the narrator's intrusion emphasizes the artificial nature of the reading experience. As with all metafiction, this blurs the boundary between real and imagined (between "regular" experience and "textually constructed" experience), because the imagined fiction enacts an "invasion" of reality—or, rather, is shown to have already invaded it. As a reader, one experiences this "invasion" of fiction (or, in other words, one becomes self-conscious that the real experience of the fiction is only imagined). This positively proves that some realities are imagined — and unavoidably suggests that the imagination plays a role in determining real experience generally (a Kantian thought).

Immediately after this metafictional introduction to the Ghost of Christmas Past, the specter is described in language and imagery that make it a clear symbol of memory, as Michael Patrick Hearn's annotations affirm (Annotated Carol 51). Thus memory personified is introduced as a faculty of the fictional imagination, or at least as a closely related representative capacity 
(making again present what is absent - in the case of memory, because it belongs to one's past experience). The Ghost conveys Scrooge to the school grounds of his childhood, where Scrooge witnesses his young self reading in the schoolroom. A second instance of patent metafiction follows - the one first alluded to above, where remembering his childhood novels moves Scrooge afresh. But the point of this metafictional moment is not only to assert the capacity of fiction to inspire: it also asserts something about the ontological status of imagined fictions. The Spirit touched him on the arm, and pointed to his younger self, intent upon his reading. Suddenly a man, in foreign garments, wonderfully real and distinct to look at, stood outside the window, with an axe stuck in his belt, and leading by the bridle an ass laden with wood. "Why, it's Ali Baba!" Scrooge exclaimed in ecstasy. 'It's dear old honest Ali Baba! Yes, yes, I know! One Christmas time, when yonder solitary child was left here all alone, he did come, for the first time, just like that. ..." To hear Scrooge expending all the earnestness of his nature on such subjects, in a most extraordinary voice between laughing and crying; and to see his heightened and excited face; would have been a surprise to his business friends in the city, indeed. (28)

Characters from Robinson Crusoe, too, make a literal appearance in this scene, and they are received as ecstatically as those from The Arabian Nights. The first metafictional moment (the appearance of the Ghost of Christmas Past) introduces Scrooge's Christmas memories as being produced by the fictional imagination; this second moment has Scrooge's memory reproducing fictional characters from his boyhood novel-reading. Once again "fiction" and "reality" blur. Scrooge is in the same spatiotemporal sphere as fictional characters. The reader is unsure whether the muse of fiction is the daughter of memory, as in Greek myth, or the reverse. Or 
perhaps both are daughters of the imaginative faculty. In any case, the memory and the fictional imagination are evidently closely related. (We might deduce this close relation without Dickens's help from the ease with which we form "memories" of early childhood experiences merely by being told about them, and then forget that the "memory" is a fiction). And if memory is "fictional," then self-identity (since it is largely a function of memory) is "fictional" in the same loose sense - and sympathy too, since the twin "fictions" of self-identity and memory are always implicated in any imaginative identification with others. The text does not explicitly go so far as this, but its clear and complex association of the memory and the fictional imagination seem purposely to lead thought in this direction.

The text makes it obvious that the reawakening of Scrooge's imagination is what reanimates his moral being, especially since one of the first things we learn about Scrooge is that he "had as little of what is called fancy about him as any man in the city of London" (14). The more interesting point from this perspective is that Dickens constantly and self-consciously places on the same ontological level the ghosts and the "real" characters, the hauntings and Scrooge's quotidian life, the narrator and the reader, the imagined and the real. Both of the explicitly metafictional moments erase the boundary between the real and the fictional by conspicuously inserting imaginative constructions into the realm of physical presence. Encouraged by this erasure, we can read all three of Scrooge's Christmas ghosts as symbols of imaginative construction as such, associated especially with the fictional imagination.

I hold with Graham Holderness, then, going further than Mary-Catherine Harrison: the spirits not only "cultivate" Scrooge's empathy by teaching him "to imagine what it is like in the Cratchit household," as Harrison puts it (263); rather, as Holderness insists, "they are the imagination ... unmistakably embodied in concrete presence" ("Imagination" 36). The 
hauntings of these three spirits explore ways in which the imagination and its "fictions" are necessary for meaningful engagement with the world.

Dickens's choice of ghosts as his personifications of the imagination participates in a cultural movement that Terry Castle traces in the shift in meaning of the word phantasmagoria. From an initial connection with something external and public (an artificially produced "spectral" illusion), the word [phantasmagoria] has now [over the past two centuries] come to refer to something wholly internal or subjective: the phantasmic imagery of the mind. This metaphoric shift bespeaks ... a very significant transformation in human consciousness ...-what I shall call the spectralization or "ghostifying" of mental space. (29)

The fictional imagination was already becoming a ghostly affair before $A$ Christmas Carol came along. Andrew H. Miller explores how this "spectralization or 'ghostifying' of mental space" played out in the representations surrounding Dickens in the public imagination, especially the many paintings of Dickens in his study, seemingly all variations on the theme of Dickens or his characters as ghostly presences. Miller argues that these paintings are informed by the spectralization of mental space. They may also be informed by A Christmas Carol, which associates both Dickens and the fictional imagination with the ghostly, practically begging for such representations.

Each of Dickens's three ghosts, from this perspective, represents a different aspect of the fictional imagination. The Spirit of Christmas Past symbolizes memory and shows how Scrooge's suppression of "the things that have been" (such as his use of the extinguisher cap to quench the light of the Ghost) has kept him from understanding his ethical state. He resists this understanding even in plain sight of the chains borne by his former partner, Jacob Marley (37, 
17-18). The Ghost of Christmas Present personifies social imaginings—communal fictions, cooperatively fabricated, which make social harmony possible. This ghost presides over the holiday as the "spirit of Christmas" in the popular sense of the phrase. Incense from his torch heightens good will and disinclines people in the streets from arguing, for they feel it "a shame to quarrel upon Christmas Day" (42). His influence similarly affects the holiday-amplified bustle of the streets, the sturdy caroling of the lighthouse crew, and the mulled-wine-merriness of Fred's Christmas party $(40,50,51)$. The implicit argument that connects this widespread good will to the imagination is that Christmas is itself a social fiction-a joint effort of imagination renewed periodically — since it is just another day until inspirited by observance. The Spirit of Christmas Yet to Come embodies imaginings of impending death. Because the Ghost's grave intimations inspire Scrooge to reconsider the rest of his life and promise reformation, this spirit symbolizes goals, intentions, and projects - imaginative projections into the future projected against the screen (or "veil") of death, the utmost mortal horizon of projects, the background against which the productive life means most fully.

All three ghosts, then, personify particular aspects of the imagination-memory, sociality, and intentions. Yet if memory, sociality, and intentions are all imaginatively constructed, as Dickens suggests, then no conceivable instant of human reality could be left untouched by the imagination, since human consciousness, all perception and all feeling, is perpetually defined by the interactions of memory, sociality, and intentions, as well as sensory input, synapse firings, and other mental functions. From this it follows that there is no pristine nonfiction if nonfiction means non-imagined - and, therefore, that the fiction/nonfiction dichotomy needs to be redefined. Within Scrooge's "real" world, this blending of the real/imaginary categories engenders perception where there had been blindness and feeling where there had been callousness: 
Scrooge is reborn as a person meaningfully engaged in his world. This rebirth, this snowy Christmas baptism, begins as Scrooge is compelled to believe in the reality of Marley's ghost (19) and concludes with his covenantal commitment: "I will honour Christmas in my heart, and try to keep it all the year. I will live in the Past, the Present, and the Future. The Spirits of all Three shall strive within me. I will not shut out the lessons that they teach" (70). In sum, Scrooge will be receptive to the ethically orienting force of the imagination, as revealed in triune form: the memory; the social imaginings that enable fellowship; and good intentions projected against the backdrop of death. All of this demonstrates the text's suggestion that perception and feeling are not only helped by a supplemental infusion of imagination but produced in a process of which the imagination is an essential part.

This is a Kantian conception. Kant's "productive imagination" is so named because it plays a primary role in producing perception (which he terms "apperception"). Kant, a crucial philosophical source for the Romantic imagination, posits the imagination as the primary synthetic faculty, making relations across time and space meaningful and thereby enabling coherent experience: "The principle of the necessary unity of the pure (productive) synthesis of the imagination prior to apperception is thus the ground of the possibility of all cognition, especially that of experience" (Kant 238). Why is this so? Kant's famously difficult prose (just now showcased) makes me turn to Christopher Long, a Kant scholar, for an intelligible explanation: the imagination "can bring Intuition 1 which is present at Time1 into relation with Intuition2 present at Time2" (239). An example might be taken from the experience of a baseball batter. The data input received as the batter sees a pitcher's windup ("Intuition1 which is present at Time1") and the data received a moment later as the baseball is released ("Intuition2 present at Time2") are not experienced as disconnected, meaningless events—rather, they bear relation to 
each other and to the batter's past experiences and current intentions. This coherence, according to Kant, is partly the result of the synthesis performed by the imagination. Long explains, "[The imagination's] function is in essence memory, for it can present an intuition that is in itself absent and thus is able to provide the requisite unity for the establishment of the flow of time" (239). As the imagination bridges temporal gaps, it likewise bridges the precognitive gap between raw sense data and the intuitions and categories that make the data meaningful, making it the "connection between sensibility and understanding" (Long 236). Similarly, A Christmas Carol diagnoses Scrooge's initial inability to engage in normal Christmas sociality as his imaginative failure to bridge the gaps separating him from his past self, from present others (his "fellow travelers to the grave") (10), and from his "nobler aspirations" (34)—so that Scrooge, having eyes, does not see what is most meaningful and stumbles toward his death as a spiritual sleepwalker, failing to recognize (as Marley's ghost points out) that "mankind was [his] business" (20).

It is unlikely that Dickens had read either Kant's Critique of Pure Reason or Coleridge's Biographia Literaria, in which Coleridge re-appropriates some of Kant's ideas on the imagination to expound upon poetic creation. Barbara Hardy rightly calls Dickens "a genius ignorant of metaphysics" (xiv), and points out that 'the terms 'fancy' and 'imagination,' firmly and famously distinguished by Coleridge ... were almost always used by Dickens interchangeably" (xv). Yet, one way or another, Dickens arrived at the notion of something like a productive imagination, perhaps absorbing it from the Romantic poets, who loved to explore the ways the imagination produces and alters consciousness.

If Dickens has deconstructed the traditional real/imaginary binary, central both then and now to the common definition of fiction, how are we to understand the difference between the 
fictional and the real within Dickens's ethical metafiction? There does seem to be a difference: if Scrooge's hauntings symbolize aspects of the fictional imagination and act on him like fictive texts act on readers, then the pre-haunting and post-haunting life would seem to symbolize "real" life. But what separates "real" life from "fiction" if both are fundamentally imagined? The text insists that Scrooge must become a different man in his post-hauntings life from the man he had been, which implies that the fictional is responsible to the real. To say this is not yet to delimit the real and the fictional, but it does suggest that what distinguishes the two is not primarily an ontological or epistemological difference, but firstly an ethical one.

The text confirms this: the difference cannot be primarily ontological or epistemological because the realms into which the spirits take Scrooge seem the same as the pre- and posthaunting realm, and his senses and faculties operate on both in the same ways: he walks about, observes, and listens as would any normal person on a ghost-guided tour. The primary difference between the real and the fictional for Scrooge is this: only in the real world does the encounter with the Other take place such that Scrooge can respond in an ethically significant way (a way that impacts others). Such an encounter I will call an "ethical encounter." In Levinasian terms, the ethical relation determines the world as real. In my view, part of this relation is the potential for ethical action on the subject's part, a potential lacking in a reader's relation to fictional characters: Scrooge can keep me company and influence me in ethically significant ways, but I cannot keep Scrooge company nor influence him, so my relation to him is not ethical in this sense.

The absence of an ethical encounter during the hauntings shows itself in Scrooge's inability to affect the lives of the people whom he encounters through the Christmas ghosts' powers. Those people are present to him but he is not present to them, as the Ghost of Christmas 
Past warns upon his first arrival at his childhood school grounds: "These are but shadows of the things that have been: they have no consciousness of us" (27). Scrooge has no choice but to be a mere observer. Clive Doner's superb adaptation, starring George C. Scott, adds to Dickens's text convincing instances in which Scrooge's attempts to say or do something during his hauntings are comically or pathetically frustrated. For example, when Fred comments that Scrooge's wealth is really of no use to him, as he doesn't even make himself comfortable with it, Scrooge replies, "I haven't squandered it, if that's what you mean by 'making myself comfortable." The ghost replies, "You mustn't argue with those in the right. It's pointless, and even tactless," a tongue-in-cheek reprimand, since Scrooge's words are "pointless" primarily because those he addresses cannot hear him. The film's reading merely amplifies what Dickens's text makes apparent: Scrooge must wait till he returns to the "real" world to act on his renewed sense of fellowship and responsibility. Upon his return, he therefore executes a lively response, for fear of becoming, when he is dead, like the damned ghosts Marley shows him, whose chief misery is that "they sought to interfere, for good, in human matters, and had lost the power for ever" (22).

If it is indeed, as I have claimed, the ethical encounter that makes Scrooge's "real world" real, then Dickens remarkably anticipates Levinas's postmodern ethical philosophy. For Levinas, it is moral consciousness that conditions both subjectivity and externality, not, as for Kant, the capacity of the subject to understand or make meaning of the external through imagination, perception, and cognition. In other words, the relationship of responsibility towards others is what defines the self as self and the world as external (external because shared with others). The Kantian concept of the imagination shows why the typical formulation of the real/fictional binary fails; this Levinasian notion of the ethical encounter gives a more adequate delineation. Both, in productive tension, are found in Dickens. 
Without the ethical encounter, being would merely be "integrated into the identity of the same"- that is, there would be nothing besides comprehension in the sense of including, containing, understanding (Levinas, "Signature" 294). Within such a world, there may not be a difference between reality and fiction. What would such a world be like — one that, lacking any ethical encounter, lacks externality? Perhaps A Christmas Carol gives some idea: Scrooge's spirit-led travels can be interpreted as a vision or dream, since the text hints that Scrooge never leaves his bedroom except in spirit, as it were. It seems almost meaningless to debate whether or not he "actually" goes to the places the spirits take him. He only integrates/comprehends the happenings. Such integration/comprehension is what Caruana calls the "ontological drama," in contrast with the "ethical intrigue." Because of the ethical encounter in the real world, there is more than comprehension, more than meaning-making: there is, even more fundamentally, ethical responsiveness and responsibility. This responsibility to an unassimilable Other is what constitutes transcendence for Levinas: "The moral consciousness ... is the very opening to exteriority" ("Signature" 294). This is why, for Levinas, "First philosophy is an ethics" (Ethics 77).

\section{A House to Let}

Levinasian ideas make themselves felt even more insistently in A House to Let, which is A Christmas Carol's thirteenth younger sibling to "haunt pleasantly" the English holiday (Preface xv). The instant and dramatic success of $A$ Christmas Carol prompted Dickens to produce a Christmas text in some form every year for the next twenty-four years except 1847 and 1849. The first four are short novels, known along with A Christmas Carol as the Christmas books, and they very obviously take $A$ Christmas Carol as their template. In each case, the plot sets up a climax of interpersonal reconciliation. A tragic ending is averted by a revelation (or 
several revelations) in which the imagination is somehow corrected, enlivened, informed, purged, or healed. Ghostly hauntings play central roles in The Chimes and The Haunted Man and the Ghost's Bargain and insistently present figments from the past figure in all of them.

After the Christmas books, Dickens turned his seasonal efforts to less demanding projects. His next two Christmas texts were relatively short meditations on Christmas, appearing during the first two Decembers of his weekly magazine Household Words, begun in 1850. From that year until 1867, Dickens published a Christmas number every year in Household Words or its successor, All the Year Round. In 1852 he began soliciting contributions from other writers, and the Christmas number became a collection of winter tales, with himself as "conductor." In 1854 he began to use a frame narrative to create coherence within the collection. It was at this stage of the Christmas numbers' development that Dickens produced A House to Let (1858), with contributions from Wilkie Collins, Elizabeth Gaskell, and Adelaide Anne Proctor. Though these developments meant that the form and authorship were more convoluted (a primary reason, no doubt, that $A$ House to Let has been neglected by critics), many of these later texts maintain significant continuity with the Christmas books. Among other things, they continue to invoke the trope of hauntings as a means to explore the ethics of fiction.

My analysis of $A$ House to Let will center on the extensive frame story, coauthored by Wilkie Collins and Dickens. It is unclear how much either writer contributed; however, inasmuch as Collins helped craft this tale, it is clear that here is no instance of Collins's subversions of Dickens's texts which Lillian Nayder's study of their partnership traces (6). Rather, the haunting in A House to Let is a direct continuation of the "spirited" ethical exploration enacted in Dickens's earlier Christmas texts. What Fruhauff's dissertation says of $A$ Christmas Carol and The Haunted Man holds true with A House to Let: all three combine 
conventions of the sentimental and the gothic for ethical effect — and the ethical meanings cohere well (Fruhauff 7). The emphasis of A House to Let is different, however. It stresses Levinasian elements rather than the imagination: its metafiction centers on the ethical encounter and explores how fiction can sometimes become an alternative to or an escape from ethical responsibility, rather than enabling renewed ethical responsiveness.

In any winter's tale of hauntings, the ghostly figure will be of primary interest. Since the metafictional focus of $A$ House to Let is the ethical encounter rather than (as in A Christmas Carol and The Haunted Man) the ethical role of the imagination or memory, this shift is reflected in the nature of the haunting itself. A House to Let has no literal (or literary) "ghost" but merely a mysterious other person — an unfortunate child, as it turns out, secretly held against his will in the adjacent house to prevent him from inheriting his mother's share of his grandfather's wealth. No ghost: only, to pun on the title of a somewhat similarly-themed text, the phantom of the operation across the street. Yet the specter of this child's presence is self-consciously tied to the ghostly, as we shall see.

The Levinasian metafiction of $A$ House to Let hinges on the scene in which this haunting begins. The protagonist, Sophonisba, a self-proclaimed old maid, finds herself staring at the house to let opposite (supposedly vacant and never let) on the first day in her new London lodgings. It is the fifth of November, the anniversary of the Gunpowder Plot, suggesting that the spirit of the sensational will animate the day. Sure enough, Sophonisba sees "a secret eye" (6), which shines in the window of the empty house (possibly reflecting the light of her fire) and then vanishes:

The eye might have seen me, or it might not have seen me, sitting there in the glow of my fire-you can take which probability you prefer, without offence- 
but something struck through my frame, as if the sparkle of this eye had been electric, and had flashed straight at me. It had such an effect upon me that I could not remain by myself, and I rang for Flobbins, and invented some little jobs for her to keep her in the room.... The impression of this eye troubled me and troubled me, until it was almost a torment ... In all this, I fully believe now, there was a good providence. But, you will judge for yourself about that, by and by.... I have heard, as everybody else has, of a spirit's haunting a house; but I have had my own personal experience of a house's haunting a spirit; for that house haunted mine. (7)

The passage emphasizes - at a length greater by many lines than what I have quoted - that this haunting is extremely important to the protagonist and to the narrative that follows, but it gives only scattered and ambiguous clues as to why.

In response to the haunting, Sophonisba enlists the investigative aid of her two closest male companions, Jabez Jarber and Trottle. Jarber is Sophonisba's would-have-been suitor, to whom the story continually attaches adjectives like "ridiculous" and "absurd" (9). Sophonisba acquaints Jarber with her concern first, though she mentions only the mystery of the house's continually un-let status and not the eye itself, and he resolves to "find out something about the house" (11). Jarber returns a few days later with two manuscripts (the stories authored by Gaskell and Dickens respectively), telling the woes of former inhabitants of the house. While Jarber is collecting his stories, Sophonisba's manservant Trottle joins his mistress in London. He is therefore present for Jarber's readings, by which time Trottle has also been told of his mistress's obsession with the house but not of the eye that caused it. The two men, a philandering servant and a rejected lover, are ironic rivals for Sophonisba's attentions. Together 
with the lovable but silly-seeming old maid they vie to impress, they make a strange and hilarious threesome, whose differing responses to the house's mysteries form a crucial part of the short novel's metafiction.

Upon hearing Jarber's readings, Trottle points out that the tales fail to address the question at issue - the reason house doesn't let and ultimately, though neither man knows it, the mystery of the eye (42-43, 54-55). Jarber's failure to answer the question suggests that he interprets the mystery's significance as essentially narrative — as Sophonisba's craving for an exciting tale, a thing to be satisfied with any good story, no matter the relevance. Sophonisba's introduction of Jarber as "a little squeezed man ... [with] little legs and a little smile, and a little voice ... [who] was always doing little errands for people, and carrying little gossip" likewise suggests that Jarber is better at telling little tales than at accomplishing significant goals (10). The way Jarber responds to Sophonisba's initial commission confirms this. The commission itself is not Sophonisba's ethical highpoint: she manipulatively uses reverse psychology, telling him that the detective work might be "too much for you" and that she is resigned to depend upon Trottle to get to the bottom of the mystery (11). He responds, "What can be done by Trottle, can be done by me. I am on terms of acquaintance with every person of responsibility in this parish. I am intimate at the circulating library...." (11-12). There is no likelihood and very little possibility that the circulating library could afford Jarber any help in solving the mystery of the house to let, yet he mentions it. Perhaps he means to emphasize his storytelling ability; certainly the circulating library associates Jarber with fictional narrative. And indeed, Sophonisba's reactions to his stories suggest that she is satisfied (almost) by the irrelevant stories he tells, for after both narratives she compliments the tales: the stories are respectively "excellent" and "delightfully amusing" $(43,54)$. Jarber's narrative play is so nearly successful that Trottle has to 
remind everyone (including the reader) that the amusement and emotion of Jarber's narratives have not fulfilled the purpose of his inquiry.

After Sophonisba hesitantly concurs with Trottle's assessment of Jarber's stories, Jarber leaves discomposed but resolved to rectify his failures. However, when he returns a week later, he has done nothing more than add another tale to the pile. Nonetheless, he seems almost hopeful that his offering will satisfy Sophonisba: "What I have gone through ... words are not eloquent enough to tell. Oh Sophonisba, I have begun another series of discoveries! Accept the last two as stories laid on your shrine; and wait to blame me for leaving your curiosity unappeased, until you have heard number three" (55). But upon completion of the third tale, Jarber recognizes that he has failed again. He returns home and falls ill, aborting his anticipated further discoveries, and never makes another appearance in A House to Let.

Meanwhile, Trottle has been making inquiries about the house across the way, and it is his turn to give an account. Sophonisba introduces Trottle's approach by contrasting it with Jarber's: “[Trottle's] promised explanation began, like Jarber's discoveries, with the reading of a written paper. The only difference was that Trottle introduced his manuscript under the name of a report" (70). "Trottle's Report," the journalistic title of the penultimate chapter of $A$ House to Let, records not what he has heard or read but rather what he has done and seen. Trottle himself also makes much of the difference between his investigative procedure and Jarber's. Referring to himself in the third person, Trottle gives this account: "Carefully dismissing from his mind all nonsensical notions of former tenants and their histories, and keeping the one point in view steadily before him, he started to reach it in the shortest way, by walking straight up to the house, and bringing himself face to face with the first person in it who opened the door to him" (71). The woman who answers the door mistakes Trottle for an expected visitor, lets him in, and 
shows him the child, who pathetically plays at scouring the floor, Cinderella-like, as "something to stand in the place of a game" (79). Trottle recognizes the woman's son - the orphan's second de facto prison keeper-and this enables him, after further research, to discover the reason for the child's imprisonment and the best way to put the matter right, which Sophonisba and Trottle proceed to do with the help of the police and a lawyer. Sophonisba adopts the child and buys the house, turning it, in the last paragraphs of the short novel, into a "hospital for sick children" (94).

The scene of the haunting eye is the origin of the subsequent plot and the story's ethical metafiction, which operates partly by contrasting the main characters' responses to the mystery. The eye's significance is initially ambiguous, but the outcome of the haunting suggests a fundamentally ethical interpretation in retrospect, as Sophonisba recognizes when she expresses faith in the "good providence" by which the haunting occurred (71). In other words, Sophonisba's ex post facto interpretation of the haunting is that she was being called in a Levinasian sense to respond to the needs of the orphan. The story therefore begs to be understood in Levinasian terms, no less because some of the text's language strikingly resembles Levinas's own. A passage from Levinas's "Signature" reads, "While the object is integrated into the identity of the Same, the Other manifests himself by the absolute resistance of his defenseless eyes" (294). The eyes, that is, infinitely resist comprehension or any totalizing effort yet are "defenseless" in that they are still subject to injury and violence—as the orphan is, socially and emotionally, if not physically. Elsewhere, Levinas refers to the manifestation of the Other as "the face." He emphasizes that the face makes ethical demands without needing first to be interpreted or understood:

I do not know if one can ... speak of a look turned toward the face, for the look is knowledge, perception. I think rather that access to the face is straightway 
ethical.... The best way of encountering the Other is not even to notice the color of his eyes! ... There is first the very uprightness of the face, its upright exposure, without defense. The skin of the face is that which stays most naked, most destitute ... there is an essential poverty in the face.... The face is signification, and signification without context.... [it] is meaning all by itself. (Ethics 86)

The eye profoundly affects Sophonisba without her noticing its color or knowing the destitution or defenselessness of its owner's circumstance, as if she straightway sees the essential poverty common to all faces. As far as the meta-commentary is concerned, the orphan's poverty and defenselessness can be read as an appropriate rhetorical symbol of the essential poverty and defenselessness of all faces, and Sophonisba's reaction to the eye as responsiveness in the face of the other. A House to Let describes this responsiveness as a "haunting"; Levinas's terms include "obsession" and "persecution" ("Substitution" 81). These terms describe the relation to the Other as something like the calling of Jonah the prophet - persevering, inescapable, even a "trauma" (Otherwise 50). Although Sophonisba's haunting is painted in strokes lightened with laughter, the scenario is no joke; her ethical calling is as serious a matter in its sphere as Nineveh's salvation.

The eye that haunts Sophonisba, then, like Levinas's description of the face, represents what is, according to Levinas, prior to representation and constitutive of subjectivity. Therefore, both Levinas and Dickens "thematize what is not thematizable," or discuss in language the ethical reality that precedes and conditions language (Ethics 107). In doing so they direct the attention from the "said" of discourse (i.e., texts themselves) to the "saying" (i.e., the speaker's acknowledgment of other people in ethical relationship with the speaker) (Ethics 87-88). Contemporary literary theory has produced a heightened awareness of the textuality of all 
discourse, including that of fiction: discourse is always and only a system of interrelated texts. Without objecting to this position, Levinas posits an ethical foundation underlying discourse (the "saying"), which arises from "the fact that before the face I do not simply remain there contemplating it, I respond to it" (Ethics 88). Appropriately, Sophonisba's haunting performs a similarly foundational function within A House to Let: it is the precondition of all subsequent narrative, the haunting revelation out of which the plot of $A$ House to Let grows. ${ }^{1}$

The contrast between Jarber and Trottle implies a judgment in favor of ethical responsibility as contrasted with purely narrative curiosity that reduces others to elements in a story and offers less possibility of ethical encounter. The very names of Jarber and Trottle, as well as their stations, seem to indicate their differing comportments: Trottle the servant trots off to be useful; the silly lover Jabez Jarber merely jabbers. He jabbers captivatingly, however, and Sophonisba is momentarily swayed to accept what Jarber can offer without pressing on to any efficacious action: if she had not recalled the ultimately ethical purpose of the investigation and gone on to intervene for the orphan, she would have failed to respond appropriately to the text's foundational mystery, the eye. This failure, averted through Trottle's influence, closely parallels what Levinas sees as philosophy's common mistake of privileging the said over the saying. For Sophonisba to remain satisfied by Jarber's offerings would be to remain dazed by the "cold splendor" that narrative offers, without offering an ethical encounter (Totality and Infinity 193).

Two other forms of privileging of the said over the saying deserve mention. According to Levinas, many first-rate philosophers have made a Jarberian mistake by assuming that the final goal is to understand or know the nature of goodness or the world or the self (i.e., to know what

\footnotetext{
${ }^{1}$ As Robert Eaglestone points out, Levinas would object to the language of foundationalism as being too "Greek." Eaglestone explains that "the relation with the other . . is not a 'foundation' in the philosophical sense. Rather, it is 'foundation without foundation,' indescribably outside discourse" (Eaglestone 150). However, "foundation without foundation" implies that the metaphor is useful, despite foundationalism's un-Levinasian associations.
} 
can be said of goodness, the world, or the self) rather than to answer the call to responsibility extended in the face of the other (Ethics 87-88). By favoring Trottle over Jarber, Dickens privileges narratives that lead to action and not only to knowledge. Trottle's report exemplifies such narrative: in response to it, Sophonisba first rescues the boy from his imprisonment, then adopts him, and finally turns the site the orphan's imprisonment (and of the past inhabitants' miseries) into a hospital for other children.

Another contemporary form of privileging the said over the saying comes when poststructuralism's hyperawareness of textuality leads to the belief that there is nothing outside of (or underlying) text, a position relevantly exemplified by Richard Rorty and Laurie Langbauer. Rorty's insistence that any theories about transcendent truth, goodness, or human nature are "outmoded," that "sad, sentimental stories" are the world's best hope for moral improvement, bears an interesting relation to Levinasian thought $(116-18,133)$. Rorty agrees that knowledge is less important than responding ethically to our fellow men; yet he implicitly denies that there is any ethical foundation for discourse. In terms of $A$ House to Let, Rorty denies the revelation of the eye as a foundational call to responsibility. He suggests that if we, as individuals and as societies, will just listen to enough of Jarber's stories, we will become the sort of people who respond appropriately to human suffering. This clearly bears a closer relation to the metafictional message of $A$ Christmas Carol than to that of $A$ House to Let, and it helps to identify more precisely the "productive tension" I have argued for between the Kantian and the Levinasian elements in Dickens.

Laurie Langbauer similarly buys into this poststructural privileging of the said over the saying in a paper about suffering children in Dickens, Dostoevsky, and Le Guin. Her primary claim is that although these authors use suffering children to condemn a world that sanctions 
such suffering, in representing it they recapitulate the voyeuristic self-concern that creates the suffering in the first place. She claims that the authors are, to some degree, aware of this but that poststructuralism helps expose our "refusal to take responsibility for our stories" and the ways our narratives attempt "to deny that rhetoric actually constructs our worlds" (103-04). Clearly Langbauer, like Levinas, is suspicious of the "cold splendor" of narrative. Yet her thought admits no concern beyond self-concern no reality behind narrative constructions. The ethics of her criticism involves no relation to the other.

The ethical imperative that we own up to our part in such constructions provides the harrowing moral of poststructural theory, and explains the resistance that prompts the turn from it, highlights the way in which ethics is actually another name for such theory. . . . I have hoped [here] to read in [a way] that accede[s] to all those difficulties but still [goes] on. (104)

This is a harrowing moral indeed, if there is nothing to do besides owning up to our complicity in cruelty, no prospect of actually redressing any wrongs or working toward a world that is more "hospitable to goodness," as Fruhauff puts it (4). Within the article, at least, Langbauer offers no grounds for such hope, basically dismissing any hope that Dickens, Dostoevsky, or Le Guin may offer. If rhetoric constructs not only “our worlds” but everything that is meaningful (something she comes close to saying), and if narrative is fundamentally ethically flawed, then after we have acceded to these difficulties, how are we to go on? There may be nothing to do except to state the damning truth in the "cold splendor" of poststructuralist prose, in which case self-condemning self-awareness is the highest good to which we can realistically aspire. Dickens, like Levinas, proposes a much more optimistic and a much more actionable ethical vision: we are called to responsibility for the other, called in the experience of 
the face (or for Sophonisba, the eye), called prior to any social or narrative constructionunambiguously, straightforwardly, and self-evidently. Or, rather, we are called other-evidently.

\section{Conclusion}

I have argued that Dickens's Christmas hauntings reach back to Kant in claiming that human reality is always imaginatively constructed but simultaneously forward to Levinas in positing the ethical relation as the fundamental (non-constructed) condition for subsequent discourse, determining fiction as fiction precisely because it lacks the externality experienced in the ethical encounter. This is significant partly because these elements of the history of philosophy are no two random tidbits. Rather, it could be argued that Kant's claim about the (imaginatively) constructed nature of reality is precisely what led to Levinas's claim that ethics is first philosophy, since Levinas's philosophy purports to uncover a genuine relation to otherness (the ethical relation) that exceeds the self-constructed reality of being/knowledge-making Levinas, in essence, an escape from the Kantian system wherein anything "in itself" ("the noumina") is not only unknowable but also meaningless. That both of these crucial philosophical moments are intimated in Dickens's Christmas hauntings evidences a complex awareness of both narrative and pre-narrative levels of ethical reality.

There remains a tension, however, between Dickens's assertion of a pre-narrative ethical reality and his emphasis on the role of fictional narratives in awakening and nurturing ethical impulses. It seems most charitable and most productive to assume that he is neither careless nor inconsistent in addressing the ethics of fiction. I am left, then, to offer what I find to be the most consistent and useful reading. Ethical responsibility is the first and great fact of society and of individuality: what Levinas calls "the face" and A House to Let "the eye" demands ethical response from the beholder. Although both Levinas and Dickens narrate the experience in 
language, Levinas insists and Dickens suggests that the epiphany of the Other is no mere effect of narrative. The reverse is the case: all culture and narrative, including fiction, finds its ultimate genesis in ethical responsiveness to others. The essential difference between fiction and reality is the presence or absence of the ethical encounter. The absence of the ethical encounter in fiction does not, however, preclude it from playing a crucial role in forming and guiding the practical expression of the fundamental unconstructed ethical sense.

Scrooge's hauntings outline some of the major ways in which this is possible. Although they involve no ethical encounter, they reawaken Scrooge's ethical being by imaginatively bridging the gaps between him and his former self, his fellow beings, and his nobler intentions. Fictions can play a role in persuading readers to ethical responsibility, even if the foundational ethical imperative comes directly from the ethical relation. In Levinasian terms, although the face speaks on its own, saying "Thou shalt not kill” (Ethics 87), fiction can and should help elaborate the point and convince readers to respond to others appropriately.

Levinas's system is not an ethics but a meta-ethics: it explains the fundamental ethical impulse but, beyond enjoining ethical response, does not explain how a person should behave. It is consistent with Levinas's philosophy for Dickens to condemn Jarber's narrative focus as inappropriate to the particular situation without condemning storytelling as such. Storytelling can still have its place, since the ways in which others are imagined (whether we choose "a generous construction [or] a mean-spirited construction") is still important. Above all, as Adam Smith rightly noted, that they are imagined is a crucial step in the development of sympathy. But it is not, as Levinas insists and Dickens suggests, the beginning of ethical meaning.

This reading of Dickens's ethical metafiction commonsensically avoids two counterintuitive extremes - condemning fiction, on the one hand, as ethically irrelevant or even 
harmful and, on the other, praising it (or cultural narratives more generally) as the sole source of ethical awareness. It takes a middle road that admits both the ethical potential and the ethical dangers of the fictional imagination, taking into account Dickens's Neo-Kantian treatment of the imagination and his Proto-Levinasian treatment of ethical responsiveness. Dickens's surprisingly nuanced meta-commentary should help him to a more distinguished place than is so far accorded him within the critical and philosophical dialogue on the ethics of fiction. 
Works Cited

Brantlinger, Patrick. The Reading Lesson: The Threat of Mass Literacy in Nineteenth-Century British Fiction. Bloomington: Indiana UP, 1998. Print.

Caruana, John. "The Drama of Being: Levinas and the History of Philosophy." Continental Philosophy Review 40.3 (2007): 251-73. Web. 1 Dec. 2012.

Castle, Terry. "Phantasmagoria: Spectral Technology and the Metaphorics of Modern Reverie." Critical Inquiry 15.1 (1988): 26-61. Web. 12 Dec. 2012.

Coleridge, Samuel Taylor. Biographia Literaria. 1817. Ed. J. Shawcross. Vol. 1. Oxford: Clarendon, 1907. Print.

Dickens, Charles. The Annotated Christmas Carol. Ed. Michael Patrick Hearn. New York: Norton, 2004. Print.

---. Bleak House. Ed. George Ford and Sylvere Monod. New York: Norton, 1977. Print.

---. A Christmas Carol. Dir. Clive Donner. Perf. George C. Scott. CBS, 1984. DVD.

---. A Christmas Carol. The Oxford Illustrated Dickens. Ed. Hablot Knight Browne. Oxford: Oxford UP, 1997. 1-80. Print.

---. The Haunted Man. The Oxford Illustrated Dickens. Ed. Hablot Knight Browne. Oxford: Oxford UP, 1997. 301-375. Print.

---. Preface. A Christmas Carol. The Oxford Illustrated Dickens. Ed. Hablot Knight Browne. Oxford: Oxford UP, 1997. xv. Print.

Dickens, Charles, Wilkie Collins, Elizabeth Cleghorn Gaskell, and Adelaide Anne Procter. $A$ House to Let. 1858. London: Hesperus, 2004. Print.

Eaglestone, Robert. Ethical Criticism: Reading After Levinas. Edinburgh: Edinburgh UP, 1997. Print. 
Fruhauff, Bradly Michael Pierson. "Dickens and the Ethics of Genre: Reading the Gothic and Sentimental After Levinas.” Diss. Loyola U, 2009. Web. 20 Sep. 2012.

Hardy, Barbara. Dickens and Creativity. London: Continuum, 2008. Print.

Harrison, Mary-Catherine. "The Paradox of Fiction and the Ethics of Empathy: Reconceiving Dickens's Realism.” Narrative 16.3 (2008): 256-78.Web. 20 Sep. 2012.

Holderness, Graham. "Imagination in “A Christmas Carol.”” Études Anglaises 32.1 (1979): 2845. Web. 1 June 2012.

Kant, Immanuel. Critique of Pure Reason. 1781. Ed. Paul Guyer and Allen W. Wood. Trans. Paul Guyer and Allen W. Wood. Cambridge: Cambridge UP, 1998. Print.

Levinas, Emmanuel. Ethics and Infinity. Trans. Richard Cohen. Pittsburgh: Duquesne UP, 1985. Print.

---. Otherwise than Being. Trans. Alphonso Lingis. 2nd ed. Boston: Nijhoff, 1978. Print.

---. "Signature.” Difficult Freedom: Essays on Judaism. Ed. Sander Gilman and Steven T. Katz. Trans. Seán Hand. Baltimore: John Hopkins UP, 1990. 291-95. Print.

---. "Substitution.” Emmanuel Levinas: Basic Philosophical Writings. Ed. Adriaan T. Peperzak, Simon Critchley, and Robert Bernasconi. Bloomington: Indiana UP, 1996. 109-28. Print. ---. Totality and Infinity: An Essay in Exteriority. Trans. Alphonso Lingis. 3rd ed. London: Kluwer, 1991. Print.

Langbauer, Laurie. "Ethics and Theory: Suffering Children in Dickens, Dostoevsky, and Le Guin.” ELH 75.1 (Spring 2008): 89-108. Web. 20 Mar. 2013.

Long, Christopher. “"Two Powers, One Ability’: The Understanding and Imagination in Kant's Critical Philosophy." Southern Journal of Philosophy 36.2 (1998): 233-53. Web. 9 Nov. 2011. 
Miller, Andrew H. “The Specters of Dickens's Study.” Narrative 5.3 (1997): 322-41. Web. 1 Oct. 2012.

Nayder, Lillian. Unequal Partners: Charles Dickens, Wilkie Collins, and Victorian Authorship. London: Cornell UP, 2002.

Nussbaum, Martha C. “The Literary Imagination in Public Life.” New Literary History 22.4 (1991): 877-910. Web. 12 Dec. 2012.

---. Love's Knowledge: Essays on Philosophy and Literature. New York: Oxford UP, 1990. Print. Reed, Jon B. “Astrophil and Estella: A Defense of Poesy.” Studies in English Literature, 1500190030.4 (Autumn 1990): 655-78. Web. 19 Mar. 2013.

Rorty, Richard. "Human Rights, Rationality, and Sentimentality." On Human Rights: The Oxford Amnesty Lectures 1993. Ed. Stephen Shute and Susan Hurley. New York: Harper Collins, 1993. 112-34. Print.

Smith, Adam. The Theory of Moral Sentiments. 1759. New York: Cambridge UP, 2002. Print. 